\title{
Study the Effect of Two Different Types of Attachment Systems on strain of Mandibular complete Overdentures Retained by Midline Implant
}

\author{
Mohamed A . Salem ${ }^{1 *}$, Mostafa M . Abd Al- Ghany ${ }^{2}$, Ehab M. Abd-Alhalim ${ }^{1}$
}

Codex : 05/2021/04

Aadj@azhar.edu.eg

\section{KEYWORDS}

Attachment Systems,

ball and equator attachments,

over denture, Platelet rich fibrin,

Implant.

1. Department of removable prosthodontics, Faculty of Dental medicine, (Assiut, Boys), Al-Azhar University, Egypt.

2. Department of removable prosthodontics, Faculty of Dental medicine, (Cairo, Girls), AlAzhar University, Egypt.

* Corresponding Author e-mail: mohamedelsayed.209@azhar.edu.eg

\begin{abstract}
Aim: This study was conducted to evaluate the effect ball and equator attachments strain (invitro study) of mandibular over denture retained by single midline implant for completely edentulous patient. Subjects and methods: Ten complete lower dentures have ball attachment and another ten complete lower dentures have equator attachment were constructed on ten acrylic models covered by rubber material to simulate oral mucosa have single midline implant, strain were evaluated around the mandibular midline implant and in the posterior area using strain meter after unilateral and bilateral loading by universal testing machine for each abutment individually. Results: When comparing strain in the peri implant area under unilateral and bilateral loading there is a significant increase in strain for ball than equator with insignificant increase in strain in the posterior area. Conclusion: According to this study strain around implant and posterior residual ridge of ball attachment more than equator one for mandibular over denture retained by single midline implant.
\end{abstract}

\section{INTRODUCTION}

Although treatment with conventional complete dentures has long been the treatment of choice in the oral rehabilitation of edentulous patients, these individuals have reported several complaints involving difficulties of adaptation,most of which have been associated with mandibular complete dentures and which include lack of retention and stability, chewing difficulties and reduced quality of life and satisfaction $^{(1)}$. Today, implant-supported mandibular overdentures retained by two implants associated with a maxillary complete denture have been proposed as the first choice of treatment for edentulous patients (2). This treatment seeks to provide better stability and retention of the mandibular complete denture, thus improving masticatory function of the patient and providing greater satisfaction, better oral healthrelated quality of life, and comfort ${ }^{(3)}$. Sufficient evidence is available to supports the suggestion that a two-implant supported mandibular 
overdenture should be suggested to edentulous patients as a first choice of treatment ${ }^{(4)}$. But, the low economic status of developing countries represents the major obstacle. Hence, the introduction of single-implant concept to stabilize the lower denture was developed as an acceptable alternative to two implant supported mandibular overdenture ${ }^{(5)}$. The selection of the attachment system has typically be empirical and based largely on the clinician's experience and preference ${ }^{(6)}$. This choice may also depend on the subjective retention characteristics of the attachment, not on scientific evidence ${ }^{(7)}$. Therefore, knowledge on the different attachment systems and an understanding of their mechanical properties (load distribution) could help clinicians to select the proper attachment for each case ${ }^{(8)}$. In addition, the performance of implant-supported overdentures depends on the retentive capacity of the attachment system employed ${ }^{(9)}$. However, two implant-supported overdenture attachment systems (Mini Ball and Equator) have recently been introduced and there is lack information about these attachments in relation to mechanical behavior. Therefore,the aim of this study was to evaluate strain characteristics (in vitro) of the Mini Ball and Equator systems on the mandibular over denture retained by midline implant.

\section{MATERIAL AND METHODS}

Ten mandibular acrylic models with twenty overdentures (ten over denture with ball and ten over denture with equator attachment) retained by midline implant were constructed.Four strain gauges wires were used in this study to record the stress distribution in implants and residual ridge. Two strain gauges were installed in the mesial and distal wall of the socket of the implant. The other two gauges were installed on the buccal side of residual ridge at the first molar areas,the wires of the strain gauges were oriented vertically in their grooves and fixed in position using an adhesive recommended by the manufacturer.To simulate oral mucosa a stone index was made on the edentulous area of the model then a round bur of $2 \mathrm{~mm}$ thickness was used to make pitting on the edentulous area and then a uniform reduction to the edentulous area was done the reduced edentulous area was painted by rubber adhesive (Zetaplus adhesive, Zhermack, Italy). Medium body rubber base was placed over the reduced edentulous area and stone index was repostioned and pressed in its place tell completely seating to produce an even thickness of medium body rubber base, even bilaterally seating pressure was applied until setting of impression material was completed.A universal testing machine was used to produce standardized static load within the physiologic limits of $50 \mathrm{~N}$ on the distal aspect of second premolar and first molar area unilaterally and bilaterally. At each site of the strain gauge strain were recorded during unilateral and bilateral loading Fig(1).

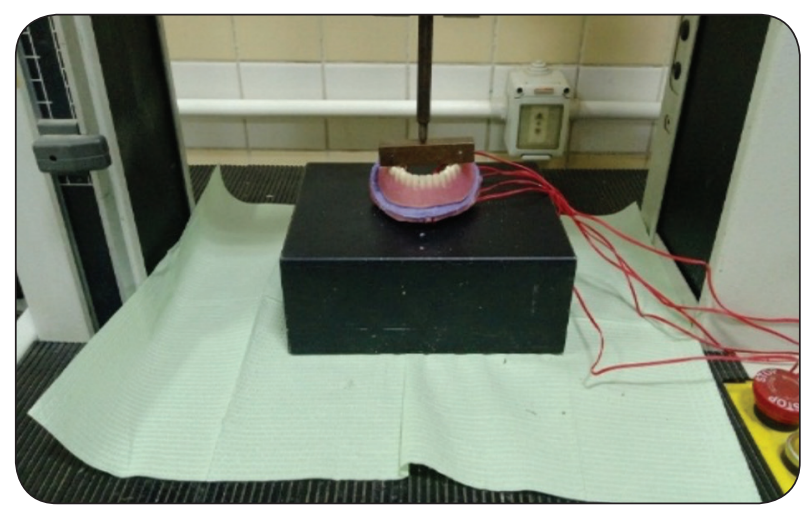

Fig. (1) Bilateral Load application to the acrylic model.

\section{RESULTS}

Table (1) Comparison of strain between ball and equator abutment under bilateral loading.

\begin{tabular}{|c|c|c|c|c|}
\hline $\begin{array}{c}\text { Strain } \\
\text { (bilateral } \\
\text { loading) }\end{array}$ & Ball $(\mathrm{n}=8)$ & Equator $(\mathrm{n}=8)$ & $\mathrm{T}$ & $\mathrm{P}$ \\
\hline $\begin{array}{c}\text { Peri } \\
\text { implant } \\
\text { area }\end{array}$ & $66.40 \pm 19.10$ & $53.60 \pm 16.80$ & $3.607^{*}$ & $0.006^{*}$ \\
\hline $\begin{array}{c}\text { Posterior } \\
\text { area }\end{array}$ & $499.80 \pm 15.38$ & $495.60 \pm 14.43$ & 1.783 & 0.108 \\
\hline
\end{tabular}




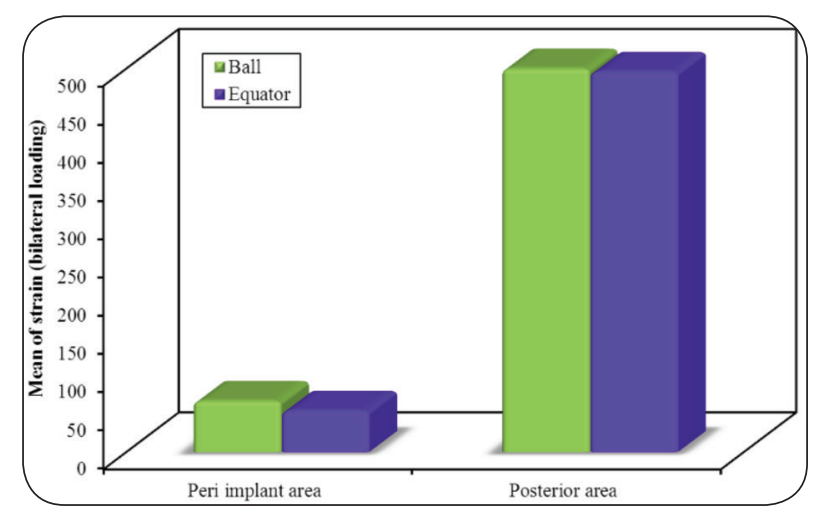

Fig. (2) Comparison of strain between ball and equator abutment under bilateral loading.

A significant increase in strain in the peri implant area for ball than equator with insignificant increase in strain in the posterior area.

\section{DISCUSSION}

This study was carried out in vitro to allow for better control over variables and to facilitate measurements of changes which occur. Stresses induced on the implants and residual ridge by different attachments were evaluate using strain gauge technology ${ }^{(10)}$. When comparing strain in the peri implant area under unilateral and bilateral loading there is a significant increase in strain for ball than equator with insignificant increase in strain in the posterior area.This may be attributed to the equator is low profile resilient attachment performance which is superior to that of the ball and socket attachment in the implant. This resiliency of the equator permits denture movement in every direction and distribution of stress induce lower stress on bone around implant of equator than ball abutment.The results also comes in agreement with previous studies that showed that the decrease marginal bone loss around the implant in crestal region which was usually a significant indicator of implant health ${ }^{(11)}$.

\section{CONCLUSION}

Strain around implant and posterior residual ridge of ball attachment more than equator one for mandibular over denture retained by single midline implant.

\section{REFERENCE}

1. Emami E, Heydecke G, Rompré PH, De Grandmont $\mathrm{P}$, Feine JS. Impact of implant support for mandibular dentures on satisfaction, oral and general health-related quality of life: a meta-analysis of randomized-controlled trials. Clinical oral implants research. 2009;20(6):533-44.

2. Marin DOM, Leite ARP, Paleari AG, Rodriguez LS, Oliveira Junior NMd, Pero AC, et al. Effect of a denture adhesive on the satisfaction and kinesiographic parameters of complete denture wearers: a cross-over randomized clinical trial. Brazilian dental journal. 2014;25(5):391-8.

3. Feine J, Carlsson G, Awad M, Chehade A, Duncan W, Gizani S, et al. The McGill consensus statement on overdentures. Quintessence Int. 2003;34(1):78-9.

4. 4.Feine J, Carlsson G, Awad M, Chehade A, Duncan W, Gizani S, et al. The McGill consensus statement on overdentures. Mandibular two-implant overdentures as first choice standard of care for edentulous patients. Gerodontology. 2002;19(1):3 .

5. Cordioli G, Majzoub Z, Castagna S. Mandibular overdentures anchored to single implants: a five-year prospective study. The Journal of prosthetic dentistry. 1997;78(2):159-65.

6. Daou EE. Biomaterial aspects: A key factor in the longevity of implant overdenture attachment systems. Journal of International Society of Preventive \& Community Dentistry. 2015;5(4):255.

7. Lee DJ. Performance of attachments used in implantsupported overdentures: review of trends in the literature. Journal of periodontal \& implant science. 2013;43(1):12-7.

8. Prasad DK, Prasad DA, Buch M. Selection of attachment systems in fabricating an implant supported overdenture. Journal of Dental Implants. 2014;4(2):176.

9. Srinivasan M, Schimmel M, Badoud I, Ammann P, Herrmann FR, Müller F. Influence of implant angulation and cyclic dislodging on the retentive force of two different overdenture attachments-an in vitro study. Clinical oral implants research. 2016;27(5):604-11.

10. Inoue $\mathrm{S}$, Kawano F, Nagao K, Matsumoto N. An in vitro study of the influence of occlusal scheme on the pressure distribution of complete denture supporting tissues. International Journal of Prosthodontics. 1996;9(2).

11. Medhat S, El Mahrouky NA, Gamal El-Din HM, Abd El Moniem NA. Evaluation of Different Attachment Systems on Single Implant Retained Mandibular Overdenture. AlAzhar Dental Journal for Girls. 2019;6(2):147-52. 


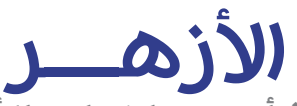 \\ مجلة أسيوط لطب الأسنان}

النشر الرسمي لكلية طب الأسنان

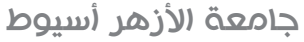

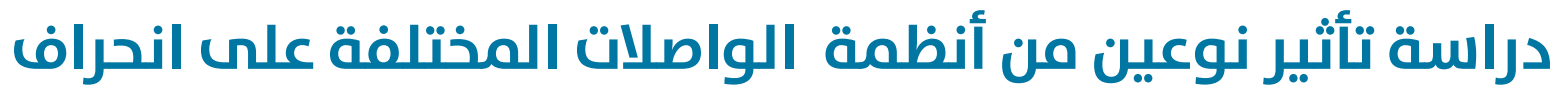

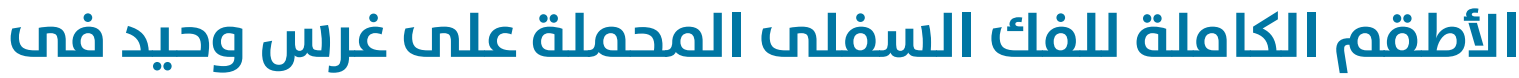 الخط المنصف.
}

\author{
محمد السيد سالم 1, مصطفي محمد عبد الغني 2, ايهاب محمد عبد الحليه1 \\ 1. 1قسـم الإستعاضـة الصناعية المتحركة؛ كلية طب الأسـنان ، (اسيوط - بنين)، جامعة الأزهر، مصر

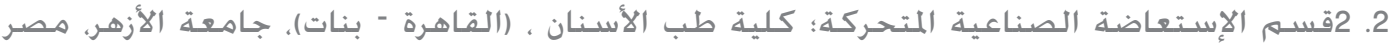

MOHAMEDELSAYED.209@AZHAR.EDU.EG البريد الإلكتروني للباحث الرئيسي *

(الملخص:

الهـدف: دراسـة تأثير نوعين من أنظمة الواصلات الغختلفة على انحراف الأطقه الكاملة للفك السفلى المحملة على غرس وحيد في الخط المنصف.

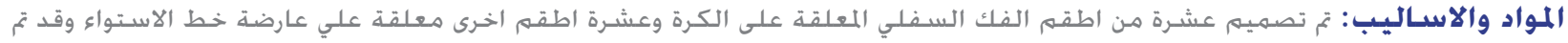

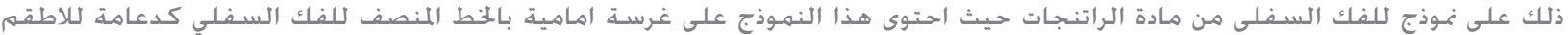

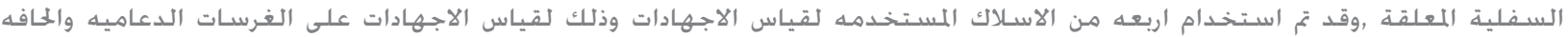

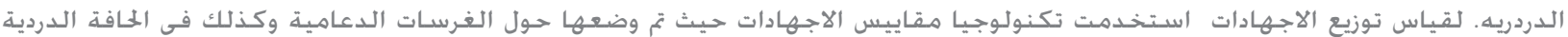

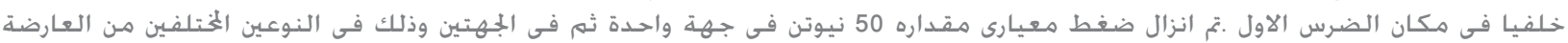
في منطقـه الضرس الاول للفك السفـلى

النتائج: تم ثلليل النتائج احصائيا وقد اظهرت الدراسـه النتائتج التاليه :الاجهادات على الغرسات الدعاميه والحافة الدردية مع الكرة كانت اكثر من عارضة خط الاستواء. الخلاصة : الاجهادات على الغرسات الدعاميه والحافة الدردية مع الكرة كانت اكثر من عارضة خط الاستواء.

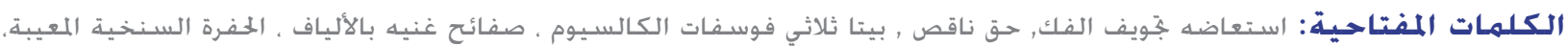

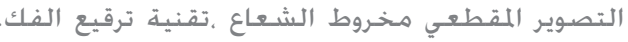

